\title{
Exploiting AT2R to Improve CD117 Stem Cell Function In Vitro and In Vivo - Perspectives for Cardiac Stem Cell Therapy
}

\author{
Marion Ludwig Anita Tölk Anna Skorska Christian Maschmeier Ralf Gaebel \\ Cornelia Aquilina Lux Gustav Steinhoff Robert David \\ Reference and Translation Centre for Cardiac Stem Cell Therapy (RTC)/Department of Cardiac Surgery, \\ University of Rostock, Germany
}

\section{Key Words}

$\mathrm{CD} 117^{+}$stem cells - Transient AT2R stimulation - Cardiac stem cell therapy • HL-1 cell line • Vasculogenesis $•$ Cardioprotection

\begin{abstract}
Background/Aims: $\mathrm{CD} 117^{+}$stem cell (SC) based therapy is considered an alternative therapeutic option for terminal heart disease. However, controversies exist on the effects of CD117+ SC implantation. In particular, the link between $\mathrm{CD} 117^{+} \mathrm{SC}$ function and angiotensinII-type-2 receptor (AT2R) after MI is continuously discussed. We therefore asked whether 1) AT2R stimulation influences $\mathrm{CD} 117^{+} \mathrm{SC}$ properties in vitro and, 2) which effects can be ascribed to AT2R stimulation in vivo. Methods: We approached AT2R stimulation with Angiotensin II while simultaneously blocking its opponent receptor AT1 with Losartan. CD117 effects were dissected using a 2D-Matrigel assay and $\mathrm{HL}-1$ co-culture in vitro. A model of myocardial infarction, in which we implanted EGFP+ CD117 SC, was further applied. Results: While we found indications for AT2R driven vasculogenesis in vitro, co-culture experiments revealed that $\mathrm{CD} 117^{+} \mathrm{SC}$ improve vitality of cardiomyocytes independently of AT2R function. Likewise, untreated $\mathrm{CD} 117^{+} \mathrm{SC}$ had a positive effect on cardiac function and acted cardioprotective in vivo. Conclusions: Therefore, our data show that transient AT2R stimulation does not significantly add to the beneficial actions of $\mathrm{CD} 117^{+} \mathrm{SC}$ in vivo. Yet, exploiting AT2R driven vasculogenis via an optimized AT2R stimulation protocol may become a promising tool for cardiac SC therapy.
\end{abstract}

Copyright $\odot 2015$ S. Karger AG, Basel

Prof. Dr. rer. nat. Robert David

KARGER 125
Reference and Translation Center for Cardiac Stem Cell Therapy (RTC)/Department of Cardiac Surgery, University of Rostock, Schillingallee 68, 18057 Rostock, (Germany) Tel. +49 381 4946215, Fax +49 381 4946214, E-Mail robert.david@med.uni-rostock.de 


\section{Cellular Physiology Cell Physiol Biochem 2015;37:77-93 \begin{tabular}{l|l} 
and Biochemistry Published online: August 17, 2015 & $\begin{array}{l}\text { C) 2015 S. Karger AG, Basel } \\
\text { www.karger.com/cpb }\end{array}$ \\
\hline
\end{tabular} \\ Ludwig et al.: Potential of AT2R for Cardiac Stem Cell Therapy}

\section{Introduction}

Stem cell therapy is considered an alternative therapeutic option for terminal heart disease. So far, different clinical trials as well as studies using animal models of myocardial infarction showed favorable outcomes following stem cell implantation [1-4]. Interestingly, any stem cell type proved to have at least some beneficial effect on cardiac regeneration following myocardial infarction (MI) [5]. However, widely accepted paracrine effects of these stem cells (SC) in terms of increasing and provoking neovascularization in the injured heart makes them promising candidates for patient-specific autologous cell therapy [6-8].

One of the bone marrow stem cell populations extensively studied are CD117+ cells. Besides controversial findings regarding their transdifferentiation potential [9-11], a number of studies point to paracrine signaling as their mechanism of action [12,13]. Infiltrating as well as the resident CD $117^{+} \mathrm{SC}$ increase their expression of VEGF, bFGF and angiopoietin and in this way, establish a pro-angiogenic milieu in the infarct border zone. This stimulation of angiogenesis and potentially myogenesis via paracrine effects in the infarcted region may play a substantially beneficial role for regeneration, as shown for various bone marrow stem cell populations [8, 12, 14-16]. In Mirotsou et al. (2011) as well as Gnecchi et al. (2008) factors involved in favorable paracrine signaling of implanted stem cells have been reviewed $[6,14]$.

Previous studies in our group extensively addressed electrophysiological characteristics of murine $\mathrm{CD} 117^{+} \mathrm{SC}$ prior to implantation $[17,18]$. As shown via whole-cell patch-clamp and immunocytochemistry, $\mathrm{CD} 117^{+} \mathrm{SC}$ rather differentiate into an endothelial-like phenotype. We hence assumed it safe to exploit $\mathrm{CD} 117^{+} \mathrm{SC}$ for myocardial regeneration, as their electrophysiological properties make it very unlikely to produce hazardous action potentials or contribute to arrhythmias as found for mesenchymal stem cells or skeletal myoblasts [19, 20].

There is evidence that an interesting link exists between $\mathrm{CD} 117^{+} \mathrm{SC}$ function and the renin-angiotensin system (RAS), which interferes with inflammation and acute cardiac remodeling processes during cardiac injury [21]. Thereby, the angiotensin II type-2 receptor (AT2R) by mediating actions of the active metabolite Angiotensin II (Ang II), opposes effects of the angiotensin II type-1 receptor (AT1R) [22, 23]. It was shown that myocardial hypoxia is associated with an increased activation of RAS, increased Ang II concentration and an increased expression of Ang II receptors [24, 25]. In cardiac regeneration, some studies showed that the AT2R acts cardioprotective, displayed by anti-inflammatory and antiapoptotic effects and improved myocardial remodeling in animal studies [21, 26, 27].

Yet in contrast, Ichihara et al. describe a negative effect of AT2R expression on cardiac remodeling. Thereby, loss of AT2R signaling was related to suppressed tissue fibrosis and abolished hypertrophic responses [28].

Seeking to resolve these obvious controversies on $\mathrm{CD} 117^{+} \mathrm{SC}$ and the influence of AT2R $[21,28]$, we indirectly stimulated AT2R signaling in murine CD $117^{+}$BMSC. After in vitro experiments, an ex vivo co-culture setup was further used to approximate the situation in vivo. Here, the influence of $\mathrm{CD}_{117^{+}} \mathrm{SC}$ on the survival of the HL-1 cardiac muscle cell line was investigated. Finally, a mouse model of myocardial infarction was used to assess cardiac function, $\mathrm{CD} 117^{+} \mathrm{BMSC}$ retention and cardioprotective effects.

In particular, we addressed the questions whether 1) AT2R stimulation influences $\mathrm{CD} 117^{+}$stem cell properties ex vivo and, 2) which specific effects can be ascribed to AT2R stimulation in vivo. We show here that indirect AT2R stimulation significantly increased $\mathrm{CD} 117^{+}$cell elongation and alignment. Untreated CD $117^{+}$SC further significantly enhanced HL-1 cardiac muscle cell line vitality via cell-to-cell contact and improved cardiac function, capillary density and collagen deposition in vivo. However, those beneficial effects could not be additionally enhanced using transient AT2R stimulation. Our results indicate a long-term reduction in eNOS and MMP-2 expression following AT2R stimulated stem cell implantation. It is likely that an altered AT2R stimulation approach for either stem cells or tissue could greatly increase beneficial effects after MI.

\section{KARGER}




\section{Cellular Physiology Cell Physiol Biochem 2015;37:77-93 \begin{tabular}{l|l|l}
\hline DOI: 10.1159/000430335 & (C) 2015 S. Karger AG, Basel
\end{tabular} and Biochemistry

\section{Materials and Methods}

Isolation and flow cytometry analysis of $C D 117^{+}$SC

$\mathrm{CD}_{117^{+}} \mathrm{SC}$ were isolated from mice femur and tibia as described before [17]. SC from lung were isolated as previously described by Fang et al. [29]. Fluorescence-activated cell analysis was performed on a FACS LSRII® (BD Biosciences) to evaluate the expression and the purity of the isolated CD $117^{+}$SC. $\mathrm{CD}_{117^{+}} \mathrm{SC}$ isolated from C57BL/6-Tg (CAG-EGFP)10sb/J (eGFP+ transgenic) mice were also analyzed for their expression of eGFP.

Cells were resuspended in DMEM (PAN Biotech, Aidenbach, Germany) containing 10\% fetal bovine serum (FBS, PAN Biotech), 100U/mL penicillin and $100 \mu \mathrm{g} / \mathrm{mL}$ streptomycin $(1 \% \mathrm{P} / \mathrm{S})$, and $1.25 \mu \mathrm{g} / \mathrm{mL}$ amphotericin B (Sigma-Aldrich). CD117 ${ }^{+}$SC were plated at a field density of $150.000 \mathrm{cells} / \mathrm{cm}^{2}$ on 12 -well plates.

AT2R stimulation of CD117+ cells

$\mathrm{CD}_{117^{+}}$cells were stimulated with $0.1 \mu \mathrm{MAngiotensin}$ II while AT1R was inhibited with $10 \mu \mathrm{M}$ Losartan (2-butyl-4-chloro-1-[p-(o-1H-tet-razol-5-ylphenyl)benzyl]imidazole-5-methanol- mono potassium salt) (both Sigma-Aldrich, Deisenhofen, Germany) for $24 \mathrm{~h}$ in culture medium (A/L stimulation). For co-culture setting, HL-1 and CD $117^{+}$SC were stimulated with A/L in the same well. The influence of A/L stimulation of HL-1 cells was assessed prior to co-culture.

Immunocytochemistry

At day 14, cultured cells were fixed with $2 \%$ formaldehyde for $10 \mathrm{~min}$ at room temperature. After permeabilization with $0.1 \%$ Triton X-100 for $20 \mathrm{~min}$ at $37^{\circ} \mathrm{C}$ and pre-blocking with DAKO Protein Block Serum free (DAKO, Hamburg, Germany), primary antibodies as polyclonal goat anti-VEGFR-2, polyclonal goat anti-CD31 (both Santa Cruz Biotechnology, Heidelberg, Germany) or anti-mouse CD45 (BioLegend, San Diego, USA) were applied overnight at $4^{\circ} \mathrm{C}$. After equilibration to room temperature, cells were washed in TBS and incubated with donkey anti-goat Alexa Fluor 488, donkey anti-goat Alexa Fluor 568 or goat anti-mouse Alexa Fluor 488 (all Invitrogen, Carlsbad, USA) for $2 \mathrm{~h}$ at $37^{\circ} \mathrm{C}$. Cells were counterstained for 10min with 4'-6-Diamidino-2- phenylindole (DAPI, Molecular Probes, Karlsruhe, Germany). For qualitative analysis, stained sections were imaged at 400x magnification on LSM 780 confocal microscope (Carl Zeiss, Jena, Germany).

\section{D-Matrigel Assay}

Freshly isolated $\mathrm{CD} 117^{+} \mathrm{SC}$ were cultured onto Matrigel in the presence or absence of A/L or AT2R

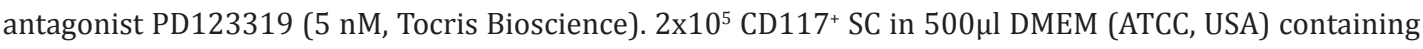
$10 \%$ horse serum (Gibco (Life Technologies), Darmstadt, Germany) and 1\% P/S were cultured on a Matrigel coated 24-well plate. Blind assessment of the extent of cell alignment was done for the three groups after 10 days. The alteration of cell alignment and sprouting was rated in 5 randomly chosen fields of the 24-well for each of the three independent experiments. Images were obtained at 100x magnification using Axiovert 40 CFL (Carl Zeiss). Scoring was as follows: - No change; + cell sprouting; ++ cell alignment in one direction.

\section{HL-1 cell line culture}

The AT-1 mouse atrial cardiomyocyte tumor lineage-derived cell line HL-1 was obtained from Claycomb Lab (LSU Health Sciences Center, New Orleans, USA). Culture protocols for HL-1 were provided by Sigma-Aldrich (SAFC Bioscience, USA). In brief, HL-1 cells were cultured as monolayer in Claycomb Medium supplemented with $10 \%$ fetal bovine serum, $1 \% \mathrm{P} / \mathrm{S}, 0.1 \mathrm{mM}$ norepinephrine and $2 \mathrm{mM}$ L-glutamine (all from Sigma-Aldrich). Well- plates for experimental purpose and tissue culture flasks were pre-coated with $0.02 \%$ gelatine and $0.0012 .5 \%$ fibronectin (both from Sigma-Aldrich). The cells were maintained at $37^{\circ} \mathrm{C}$ and $5 \% \mathrm{CO}_{2}$.

HL-1-CD117 co-culture setting and hypoxia

To distinguish HL-1 from CD117 ${ }^{+}$SC in direct co-culture setting, cells were labeled with either Vybrant $^{\text {TM }}$ Dye DiI (HL-1; prior to culture) (Life Technologies) or anti-mouse CD45 (CD117 ${ }^{+}$SC, prior to 


\section{Cellular Physiology Cell Physiol Biochem 2015;37:77-93 \\ \begin{tabular}{l|l|l}
\hline DOI: 10.1159/000430335 & C 2015 S. Karger AG, Basel
\end{tabular} \\ \begin{tabular}{l|l} 
and Biochemistry Published online: August 17, 2015 & www.karger.com/cpb
\end{tabular} \\ Ludwig et al.: Potential of AT2R for Cardiac Stem Cell Therapy}

immunocytochemistry). Dil labeling time was 10 min for HL-1 cells. CD45 is not expressed in HL-1 cell line and can thus be used to distinguish cell types during immunocytochemistry.

For co-culture, HL- 1 cells were seeded at a density of 70.000 cells per 24 -well and 300.000 cells per 6-well in Claycomb Supplemented Medium. The isolated CD117 ${ }^{+}$cells were added to the adherent HL-1 cells in a ratio of 1:2. The co-culturing of both cell types was performed either with direct cell-to-cell contact or without cell-to-cell contact using Millicell $®$ Cell culture inserts $(0.4 \mu \mathrm{m}$ PCF, $12 \mathrm{~mm}$ diameter; Millipore Ireland Ltd.). Cells were co-cultured for $24 \mathrm{~h}$ before they were subjected to hypoxic conditions for another $24 \mathrm{~h}$.

To expose cells to a hypoxic environment, oxygen was replaced in a Modular Incubator Chamber MIC 101, (billups-rothenberg, USA) by stream in of nitrogen in the airtight locked chamber.

\section{MTT-assay}

Before MTT-assay CD117 ${ }^{+}$cells were washed off with three subsequent medium changes. After $48 \mathrm{~h}$ of co-culture (with or without hypoxia) MTT ( $5 \mathrm{mg} / \mathrm{ml}$ in PBS) was added to the HL-1 cells and incubated for $4 \mathrm{~h}$ at $37^{\circ} \mathrm{C}$. Then medium was removed completely and dimethylsulfoxide (DMSO) was added until formazan was completely dissolved. $100 \mu \mathrm{l}$ per well were transferred in 96-well plates in triplicates and absorbance was measured at 550nm and 655nm (reference wavelength) using a Microplate Reader (Model 680, Bio-Rad Laboratories GmbH, München, Germany). The results were given as the percentage of vitality in respect to the single culture of HL-1 cells under normoxic conditions (set to 100\%).

\section{Quantitative real time PCR analysis}

For analysis of AT2R stimulation, RNA from $1 \times 10^{6} \mathrm{CD} 117^{+} \mathrm{SC}$ in the presence or absence of A/L or PD123319 was isolated following the instructions of TRIzol Reagent (Life Technologies). Samples were analyzed with NanoDrop1000 (Thermo Scientific, Karlsruhe, Germany) to demonstrate consistent quality and to determine RNA concentration. The RNA was reversed to cDNA using $\mathrm{RT}^{2}$ first strand kit (SABiosciences, Qiagen, Hilden, Germany). The realtime PCR procedures were performed using $\mathrm{RT}^{2}$ SYBR Green/Rox qPCR master mix reagent (SABiosciences). Angiotensin II type 2 receptor (AT2R; PPM04811A) expression levels were normalized to the expression of GAPDH housekeeping gene (PPM02946E). Primer were purchased from SABiosciences (RT2 ${ }^{2} \mathrm{PCR}$ Primer Assays).

Hearts were removed, embedded in O.C.T. ${ }^{\mathrm{TM}}$ Compound (Tissue-Tek $®$; Zoeterwoude, Niederlande) and snap-frozen in liquid nitrogen. Tissue RNA was isolated following the same protocol of TRIzol Reagent and reversed to cDNA using High Capacity cDNA Reverse Transcription Kit (Applied Biosystems (Life Technologies), Darmstadt, Germany). Primer sets for RT-PCR were purchased from Applied Biosystems: enhanced GFP (Mr04329676_mr); Cxcl12 (Mm00445553_m1); eNOS (Mm00435217_m1); MMP-2 (Mm00439506_m1); CD34 (Mm00519283_m1); BAX (Mm00432051_m1) and Bcl-2 (Mm00477631_m1). Amplification and detection were performed with the StepOnePlus ${ }^{T M}$ Real-Time PCR System (Applied Biosystems) in TaqMan Universal Master Mix (Applied Biosystems) according to the instructions of the manufacturer (Applied Biosystems). DNA extracts were tested in triplicate and negative controls were included in each assay. Cycle thresholds $\left(C_{t}\right)$ for single reactions were determined with StepOne ${ }^{\mathrm{TM}}$ Software 2.0 (Applied Biosystems) and the target genes were normalized against GAPDH. Resulting $\Delta \mathrm{C}_{\mathrm{t}}$ of triplicates was averaged and $\Delta \Delta \mathrm{C}_{\mathrm{t}}$ were obtained using Sham group as calibrator sample. The $2^{-\Delta \Delta \mathrm{ct}}$ method was employed to present the changes in gene expression as $\mathrm{x}$-fold change.

EGFP expression levels are given as $\Delta \mathrm{C}_{\mathrm{t}}$ (cycle threshold difference between EGFP and GAPDH) as EGFP is not expressed in Sham and MI-C.

\section{Cell sorting and colony forming units-assay}

CFU assay was used to analyze the stability of eGFP protein expression in CD117 ${ }^{+}$cells. CD117 ${ }^{+}$ cells were sorted with BD FACS Aria (gating: viable eGFP+CD117 ${ }^{+}$cells) and subjected to CFU assay. For one experiment, $5 \times 10^{4}$ freshly isolated $\mathrm{CD}_{11} 17^{+}$cells were mixed with $2 \mathrm{ml}$ Metho Cult Medium (Mouse Colony-forming unit assay, M3334, StemCell Technologies, Cologne, Germany). CD117 ${ }^{+}$cells were cultured as triplicates for 12 days at $37^{\circ} \mathrm{C}, 5 \% \mathrm{CO}$. Cells were released from the gel using $1 \mathrm{ml}$ Dispase (StemCell Technologies) per dish and analyzed for eGFP expression with BD FACS Aria. 


\section{Cellular Physiology Cell Physiol Biochem 2015;37:77-93 \begin{tabular}{l|l|l}
\hline DOI: 10.1159/000430335 & (C)15 S. Karger AG, Basel
\end{tabular} and Biochemistry Published online: August 17, $2015 \quad$ www.karger.com/cpb \\ Ludwig et al.: Potential of AT2R for Cardiac Stem Cell Therapy}

Immunohistochemistry

For immunohistological detection of eGFP+ and VEGF+ stem cells, frozen transverse tissue sections $(6 \mu \mathrm{m})$ of hearts from MI-C and Sham were incubated with goat anti-GFP (conjugated to FITC) (Abcam, Cambridge, UK; ab6662) and rabbit anti-VEGF polyclonal antibodies (Santa Cruz Biotechnology, sc-507). Subsequently, the sections were incubated with donkey anti-rabbit Alexa-Fluor 568 conjugated secondary antibody (Life Technologies). Nuclei were counterstained with DAPI (Molecular Probes). Labelled sections were observed using LSM 780 confocal microscope (Carl Zeiss). Hearts were analyzed 24h, 48h, and 7d after cell injection.

\section{Experimental design of the animal model}

The federal animal care committee of LALLF Mecklenburg-Vorpommern (Germany) approved the study protocol (LALLF M-V/TSD/7221.3-1.1-050/12). Male eGFP-transgenic mice (C57BL/6-Tg(CAGEGFP)10sb/J) and male C57Bl6/J mice were purchased from Charles River Laboratories (Sulzfeld, Germany). EGFP-transgenic mice served as CD117+ SC donor. C57BL6/J mice (Charles River Laboratories) were randomly assigned to 4 groups: Sham operation with BD Matrigel ${ }^{\mathrm{TM}}$ Matrix (Matrigel) (BD Biosciences USA) injection (Sham, $n=6$ ), myocardial infarction (MI) with Matrigel injection (MI-C; $n=6)$ and two MI groups with implanted CD117 ${ }^{+}$SC (in Matrigel) with the respective treatment (MI-CD117; MI-CD117+A/L; $n=6$ ). Mice were assessed for functional measurement, histological and qRT-PCR evaluation at three weeks after surgery.

Generation of MI in mouse and intramyocardial stem cell injection

Mice were anesthetized with pentobarbital (50 $\mathrm{g} / \mathrm{g}$ body weight). After thoracotomy and preparation, the left anterior descending coronary artery (LAD) was permanently ligated. Immediately after LADligation, each mouse received an intramyocardial injection of $2 \times 10^{5} \mathrm{CD} 117^{+}( \pm 24 \mathrm{~h}$ of AT2R stimulation) SC in Matrigel, or Matrigel alone for MI-C. Along the border of the blanched myocardium $3 \times 5 \mu$ injections were given. Sham operated mice underwent identical surgical procedures without LAD-ligation but followed by intramyocardial Matrigel injection without cells.

\section{Left ventricular catheterization}

Three weeks after surgery, mice underwent pressure-volume (P/V) loop measurements according to the protocol of CardioDynamics BV (CD Leycom, Zoetermeer, Netherlands) and as established before by our group [30]. Data were collected with the Millar Pressure-Volume System (Ultra-Miniature Pressure-Volume Catheter (model SPR-1030), Millar Pressure Conductance Unit (model MPCU-200) and Millar PowerLab data-acquisition hardware; emka Technologies, Paris, France). Calibration of pressure and volume was performed by equating the minimal $(0 \mathrm{mmHg})$ and maximal $(100 \mathrm{mmHg})$ conductances. After inserting the catheter into the carotid artery, retrograde access to the left ventricle (LV) was achieved. P/V loops were recorded under normal conditions (baseline) followed by stress conditions mediated by intravenous dobutamine administration $(10 \mu \mathrm{g} / \mathrm{kg} / \mathrm{min}$, Sigma-Aldrich). Volume signal was corrected by measurement of wall conductance (parallel volume) via hypertonic saline (5\%) injection. Data were analyzed with IOX Version 1.8.3.20 software (emka Technologies). After P/V loop measurements, mice were euthanized by a single dose of potassium chloride to arrest hearts in diastole. Each heart was removed, embedded in 0.C.T. ${ }^{\mathrm{TM}}$ Compound and snap-frozen in liquid nitrogen. For histological and biomolecular investigations the heart tissue has been divided into 4 horizontal levels from top to bottom and, within each, sections of $6 \mu \mathrm{m}$ were cut. The three interlayers between the mentioned levels have been collected separately for RNA isolation.

Determination of functional perfusion and capillary density

Heart sections of 4 horizontal infarct levels $(6 \mu \mathrm{m})$ were stained with Fast Green FCF (Sigma-Aldrich) and Sirius Red (Division Chroma, Münster, Germany). To evaluate fibrosis ( $\mathrm{n}=5$ for each group), the Sirius red positive regions of collagen deposition in the remote area (RA) near endocardial border and in the border zone (BZ) of the infarcted area were examined in 5 randomly chosen fields per section (one section per level; 400x) using computerized planimetry (Axio Vision LE Rel. 4.5 software; Carl Zeiss). Collagen density was expressed as the ratio of collagen deposition to myocardial tissue in percentage.

After termination of $\mathrm{P} / \mathrm{V}$ loop measurements and before euthanasia, mice were perfused with biotinylated lycopersicon esculentum (tomato) lectin $(200 \mu \mathrm{g}$ in $250 \mu \mathrm{l} 0.9 \% \mathrm{NaCl}$; Vector Labs, USA) for 


\section{Cellular Physiology Cell Physiol Biochem 2015;37:77-93 \\ \begin{tabular}{l|l|l}
\hline DOI: 10.1159/000430335 & (C) 2015 S. Karger AG, Basel
\end{tabular} \\ www.karger.com/cpb \\ Ludwig et al.: Potential of AT2R for Cardiac Stem Cell Therapy}

$10 \mathrm{~min}$ using the canula inserted in the jugular vein. Direct contact of lectin with endothelial cells is required for labeling. Therefore, vessels that are not perfused will not be labeled with lectin. Heart sections of 4 horizontal infarct levels were stained with goat anti-biotin (Vector Labs) and in a second step with donkey anti-goat Alexa Fluor 568 (Life Technologies).

Capillary density was assessed by counting the number of capillaries in 5 RA and 5 BZ randomlychosen fields (400x). Results were expressed as capillaries per high power field (HPF).

Data Analysis

Statistical analyses were performed using GraphPad Prism software version 5.0. Results were expressed as mean \pm SEM. Two-group comparisons were analyzed by two-tailed Student t-test. Log-rank test was applied to analyze Kaplan-Meier survival curve. P-values $<0.05$ were considered statistically significant. Data plots were created using GraphPad Prism software version 5.0.

\section{Results}

Stimulation for AT2R significantly elevates AT2R mRNA expression

$\mathrm{CD} 117^{+} \mathrm{SC}$ were isolated using MACS and purity was determined using FACS analysis. Only isolations with a purity of at least $80 \%$ were used for further experiments as previously established by us [17]. The efficiency of AT2R stimulation with Angiotensin II (while AT1R was inhibited with Losartan; (A/L stimulation)) was verified by qRT-PCR, showing an 11.38 \pm 2.71 -fold $(n=5)$ elevated AT2R mRNA expression compared to unstimulated control cells (Fig. 1). Following AT2R inhibition with its antagonist PD123319, AT2R mRNA was detectable in only 2 out of $5 \mathrm{CD} 117^{+} \mathrm{SC}$ samples and downregulated AT2R mRNA levels to those observed in control cells (Fig. 1).

\section{CD117+ SC increase HL-1 vitality in direct co-culture setting}

To approximate the in vivo situation, we used HL-1 cells, a cardiac muscle cell line derived from the AT-1 mouse atrial cardiomycyte tumor lineage, known to have the ability to express cardiac markers and to contract after stimulation in a co-culture setup. The influence of $\mathrm{CD}_{117^{+}} \mathrm{SC}$ on HL-1 vitality was assessed using the MTT-assay. CD117 ${ }^{+} \mathrm{SC}( \pm$ AT2R stimulation) were cultured together with HL-1 cells in a ratio of 1:2 under normoxic and hypoxic conditions. Under both conditions, co-culture with untreated $\mathrm{CD}_{117^{+}} \mathrm{SC}$ significantly increased HL-1 vitality as compared to single HL-1 culture (normoxia: $+9.4 \%$ $\mathrm{p}<0.01$; hypoxia: $+2.6 \% \mathrm{p}<0.05 ; \mathrm{n}=4$ ). The additional treatment with $\mathrm{A} / \mathrm{L}$ attenuated this effect (Fig. 2a). The role of AT2R in Ang II-mediated apoptosis has been controversially discussed before and seems to differ between the investigated cell types. In this HL-1 coculture, stimulation of $\mathrm{CD} 117^{+} \mathrm{SC}$ indicates a reversal of anti-apoptotic effects via AT2R. To determine whether direct cell-to-cell contact is necessary for this beneficial effect, cell types were separated by a cell culture insert (filter). No significant differences in HL-1 vitality were detectable when cultured without cell-to-cell contact (Fig. 2b). The influence of Ang

Fig. 1. Quantitative real-time PCR analysis of AT2R mRNA. CD117+ SC were treated with A/L or PD123319 for 24h. Only 2 out of 5 experiments showed AT2R expression after PD123319 treatment. The mean mRNA expression levels of untreated control $\mathrm{CD} 117^{+} \mathrm{SC}$ were arbitrarily given a value of $1\left(2^{0}\right)$ as indicated by red arrow. Expression levels were normalized to the expression of GAPDH. Data given as mean $\pm S E M ; n=5$.

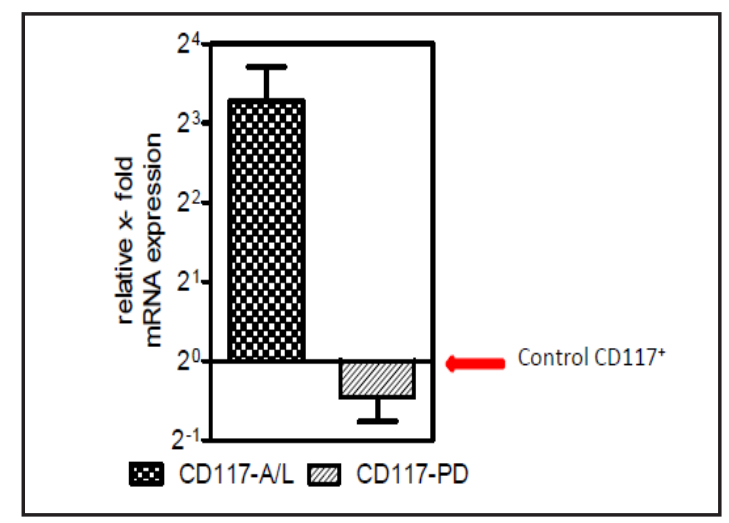




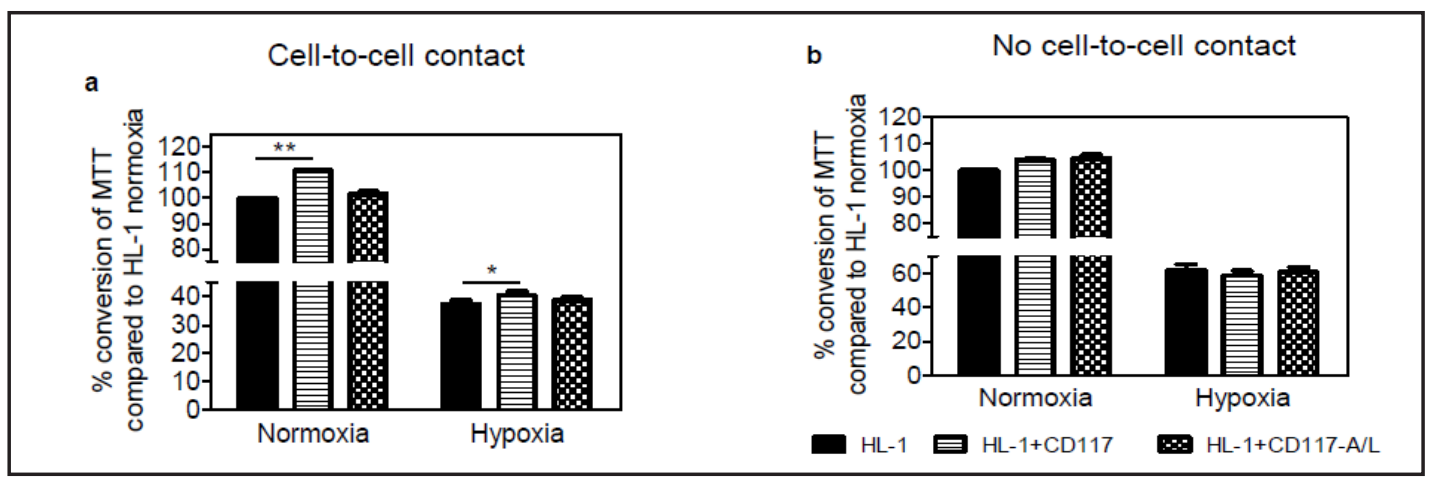

Fig. 2. HL-1 vitality in single culture and co-culture with CD $117^{+}$cells $( \pm A / L)$. (a) Bar charts illustrate HL-1 vitality determined by MTT -assay after $48 \mathrm{~h}$ in culture with or without the addition of CD $117^{+}$SC. Hypoxia treated groups underwent oxygen deprivation for $24 \mathrm{~h}$. A significant increase of HL-1 vitality was detectable following CD117 addition, if cells were cultured with cell-to-cell contact ( $n=4$, in duplicates), (b) but not if an inlet filter was used, which prevented HL-1 and CD $117^{+}$SC cell-to-cell contact ( $\mathrm{n}=2$, in duplicates). Data given as mean $\pm \mathrm{SEM}$; ${ }^{* *} \mathrm{p}<0.01$ vs. normoxic HL-1 group; ${ }^{*} \mathrm{p}<0.05$ vs. hypoxic HL-1 group.

Fig. 3. Immunofluorescence analysis of $\mathrm{CD}_{117^{+}} \mathrm{SC}$ in HL-1 co-culture setting. Representative image of stained 6-day co-cultured HL-1 and $\mathrm{CD}_{117^{+}}$SC showed specific signals for endothelial marker (a) CD31 and (b) VEGFR-2. Panhematopoietic marker CD45 was used to distinguish CD117 cells from HL-1 cell line. Cells were stained using anti-CD31 (Alexa Fluor 488), anti-CD45 (Alexa Fluor 568), anti-VEGFR-2 (Alexa Fluor 488) and DAPI (blue) for nuclei counterstaining. HL-1 cells were labeled with Vybrant Dye DiI prior to co-culture. Scale bars: $5 \mu \mathrm{m}$. Images were acquired with 400x magnification using LSM 780 confocal microscope (Carl Zeiss).

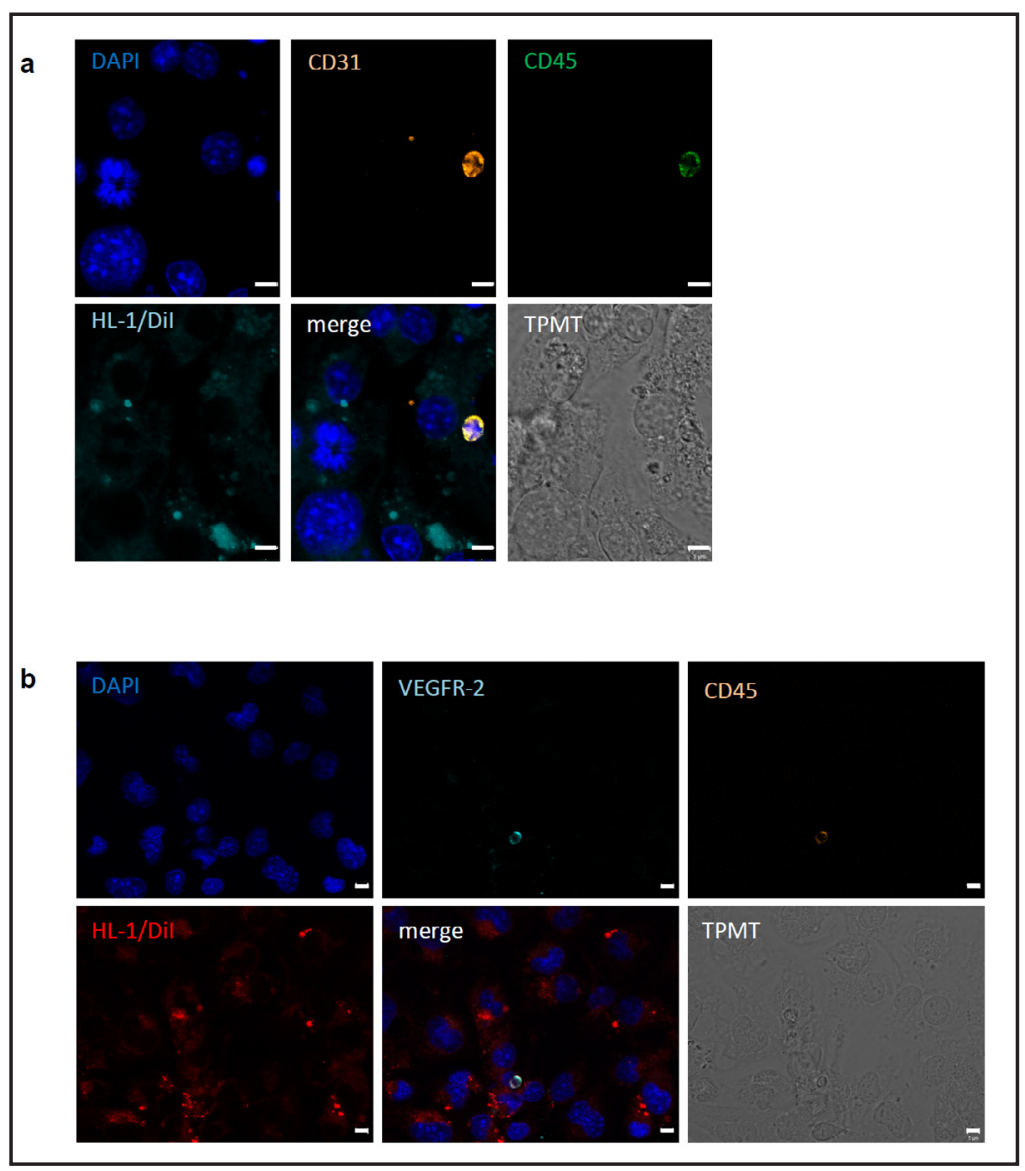

II, Losartan or A/L treatment on HL-1 cell vitality was assessed in advance and yielded no changes in HL-1 vitality (data not shown).

Upon co-culture, CD117 ${ }^{+}$cells were distinguished from HL-1 cells based on CD45 expression analysis, since HL-1 cells do not express CD45. Thereby, after six days in coculture, CD117 ${ }^{+}$SC expressed endothelial cell surface markers VEGFR-2 and CD31 (Fig. $3 \mathrm{a}+\mathrm{b}$ ). The expression of CD31 on $\mathrm{CD} 117^{+} \mathrm{SC}$ (single culture) was previously described and shown by our group [17].

\section{KARGER}



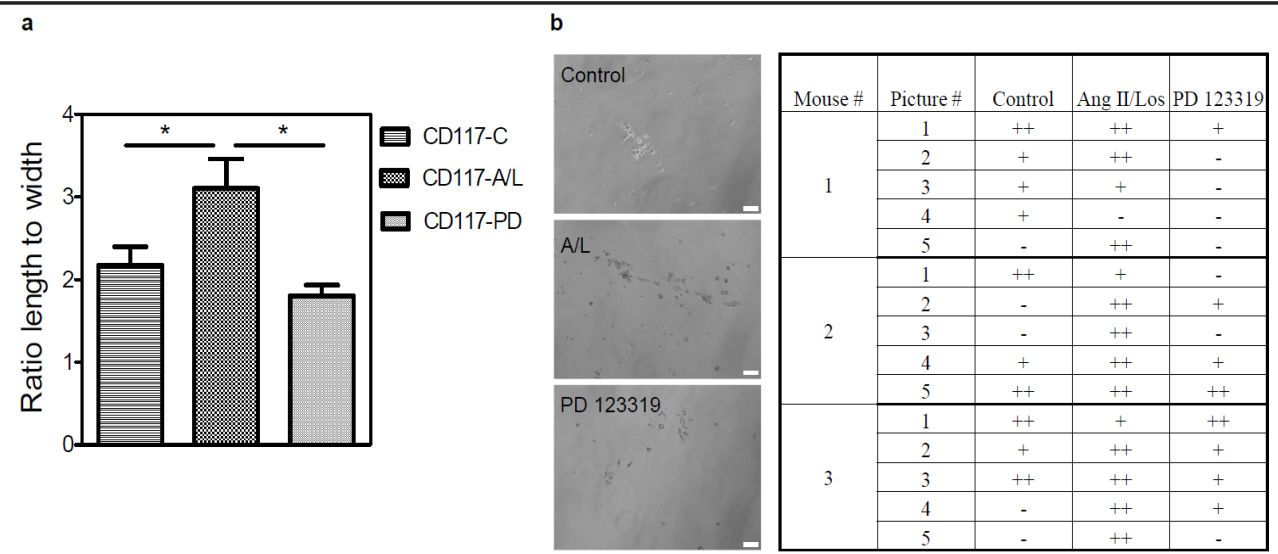

Fig. 4. Analysis of endothelial properties of $\mathrm{CD} 117^{+}$SC. (a) The ratio length to width was analyzed as a measure of cell elongation following a 2-D Matrigel Assay. Five cells in each 5 random fields of view were blindly assessed in three independent experiments. Width and length of chosen cells were measured using ImageJ software. The influence of AT2R treatment and inhibition was compared to control CD117 ${ }^{+}$SC. $\mathrm{n}=3$; $^{*} \mathrm{p}<0.001$ vs. CD117 control; $\# \mathrm{p}<0.05$ vs. CD117+PD 123319. Data given as mean \pm SEM. (b) Images are representative for cell alignment of the three groups in a 2-D Matrigel assay. Cell alignment was blindly assessed in three independent experiments. For each experiment five cells in five pictures (100x) were evaluated. Scale bar: $20 \mu \mathrm{m}$. Scores were as follows: - No change; + cell sprouting; ++ cell alignment in one direction.

\section{AT2R stimulation significantly increases CD117+ cell elongation ratio}

A 2-D BD Matrigel ${ }^{\mathrm{TM}}$ Matrix (Matrigel) in vitro assay was deployed to investigate influences of stimulation on cell alignment and cell morphology. The elongation ratio (length-to-width) of AT2R stimulated cells $(3.1 \pm 0.4 ; n=3)$ was significantly increased 1.4fold compared to control $\left(2.2 \pm 0.2 ;{ }^{*} \mathrm{p}<0.03 ; \mathrm{n}=3\right)$ and 1.7 -fold compared to PD123319 $(1.8 \pm 0.1 ; \# p<0.0009 ; n=3)$ treated cells (Fig. 4a). We also observed elevated cell alignment and sprouting following A/L addition compared to control and PD123319 treated cells as analyzed with blind assessment (Fig. 4b). Therefore, the AT2R stimulation might be a relevant factor to induce changes in cell morphology as shown here for CD117 ${ }^{+}$SC. This data supports a previous study [17] indicating that AT2R stimulation could be involved in an endothelial-like differentiation of stem cells.

Intramyocardial injection of CD117+ SC improves cardiac function and survival rate

The implantation of $\mathrm{CD}_{117^{+}} \mathrm{SC}$ improved left ventricular functions mostly independent of AT2R stimulation (Fig. 5). The ejection fraction was significantly increased following $\mathrm{CD}_{117^{+}}$SC implantation, while the cardiac output was significantly elevated after AT2R stimulation if compared to the MI-C group (Fig. 5a+b). However, AT2R stimulation did not generally enhance the beneficial effects of $\mathrm{CD} 117^{+} \mathrm{SC}$ implantation. The reversal of an antiapoptotic effect of $\mathrm{CD} 117^{+} \mathrm{SC}$ following AT2R stimulation as demonstrated with HL-1 cardiac muscle cell line might be responsible for the inconsistent cardiac function. Heart weight/ body weight ratio, which is a commonly used index of cardiac hypertrophy, significantly decreased in the groups with implanted cells (Fig. 6a). Mortality was reduced, but did not reach significance as determined with Log-rank test $(\mathrm{p}=0.209$ MI-CD117+A/L compared to MI-C) (Fig. 6b).

\section{SC implantation significantly reduces collagen deposition and capillary density}

The implantation of $\mathrm{CD} 117^{+}$SC resulted in a significantly increased capillary density (Fig. 7) and a significantly decreased collagen deposition (Fig. 8). AT2R stimulation could not further restore capillary density or collagen deposition. 
Fig. 5. Cardiac functions three weeks after MI. (a) Left ventricular functions at both baseline and stress (dobutamine) conditions were assessed by catheterization. Maximal intraventricular developed pressure was increased in both SC implanted groups compard to MI-C. (b) Ejection fraction and (c) cardiac output were significantly increased in MI-CD117 and MICD117+A/L group, respectively, under both treatment conditions. (d) Endsystolic pressure was significantly improved in MI-CD117+A/L group compared to MI-C under stress conditions. Data given as mean $\pm \mathrm{SEM}$; $\mathrm{n}=6$; ${ }^{*} \mathrm{p}<0.05$; $^{* *} \mathrm{p}<0.01$ vs. MI-C.
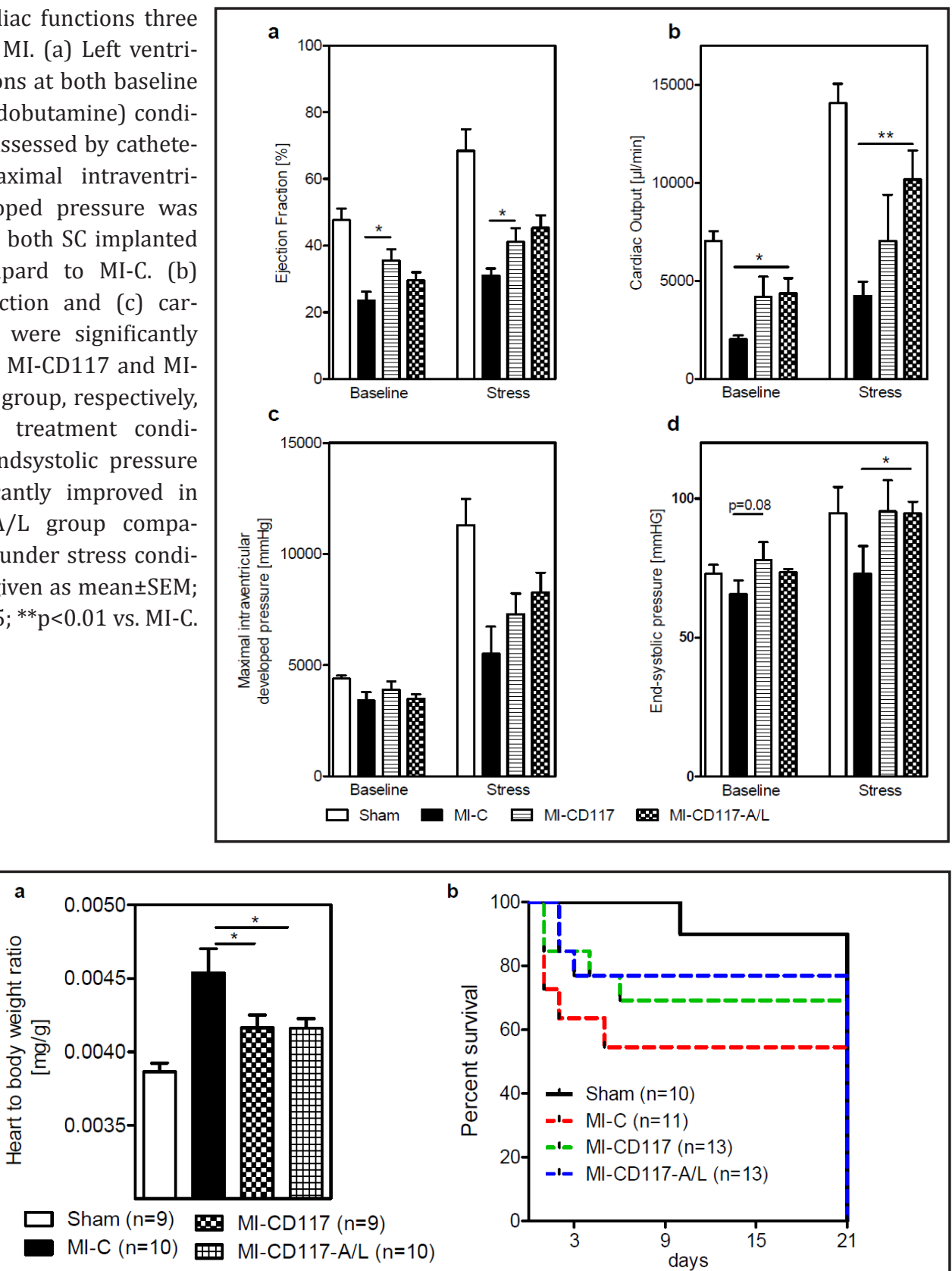

Fig. 6. Improved heart to body weight ratio and mortality 3 weeks after MI. (a) Statistical analysis showed the tendency of improved heart to body weight ratio following SC implantation, which did not reach statistical significance (Student's t-test). (b) Therapy related survival rates [\%] did not significantly differ among the MI groups as determined with Log-rank test. Data given as mean \pm SEM.

Collagen deposition in the BZ decreased significantly from $25.53 \pm 1.43 \%$ in MI-C to $14.81 \pm 0.69 \%$ in MI-CD117 ( $<<0.01$, Fig. $4 a+b)$ and $16.92 \pm 0.59 \%$ in MI-CD $117+A / L(p<0.05$, Fig. 8a+b), respectively. Hearts implanted with SC also showed a significant reduction of collagen deposition rate in the remote area (Fig. 8b). Fig. 8a shows representative staining images of collagen deposition (Sirius Red) and myocytes (Fast Green) in the BZ.

Capillary density was determined based on tomato lectin perfusion. Compared to MI-C (22.47 \pm 0.9 capillaries per HPF), capillary density in the BZ significantly increased upon SC transplantation (MI-CD117: $35.79 \pm 1.82$; MI-CD117+A/L: $30.55 \pm 2.61$ capillaries per HPF) (Fig. 7a+b). 


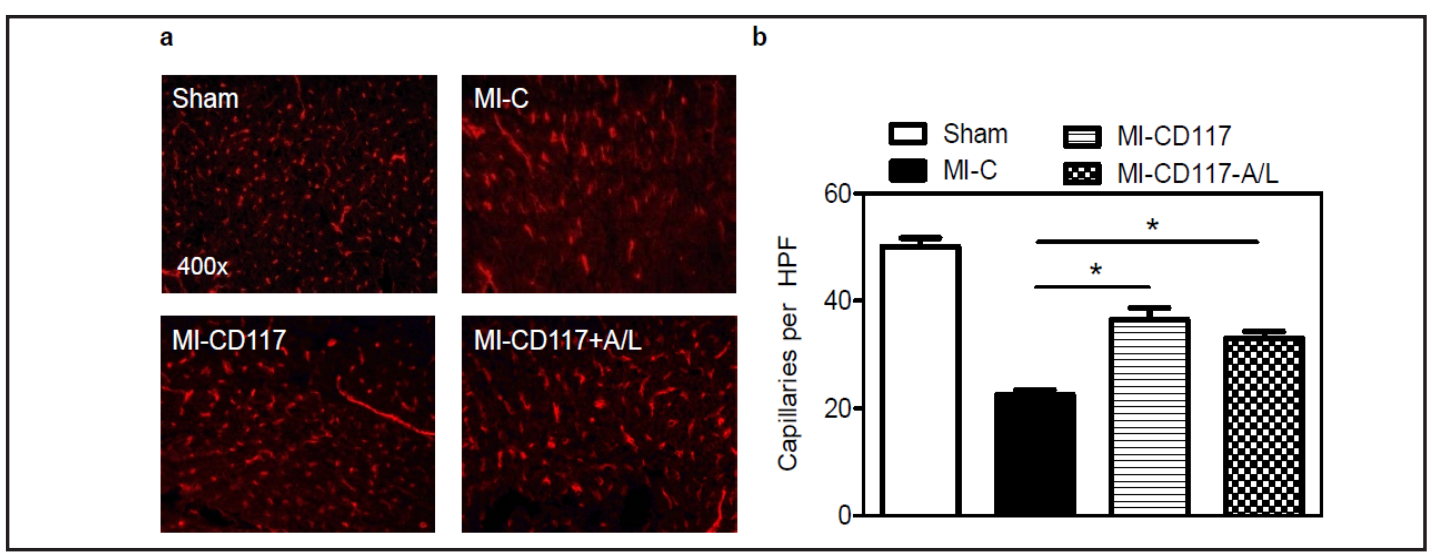

Fig. 7. Increased capillary density in remote area of infarct zone. Representative biotinylated tomato lectin perfusion staining in remote area of infarct zone of (a) Sham, (b) MI-C, (c) MI-CD117 and (d) MI-CD117+A/L. Bound lectin was stained with AlexaFluor 568 secondary antibody (A-D). (e) Capillary density in the remote area is significantly increased following SC implantation 3 weeks after MI. Data given as mean \pm SEM. ${ }^{*} \mathrm{p}<0.01$ vs. MI-C; $n=5$.

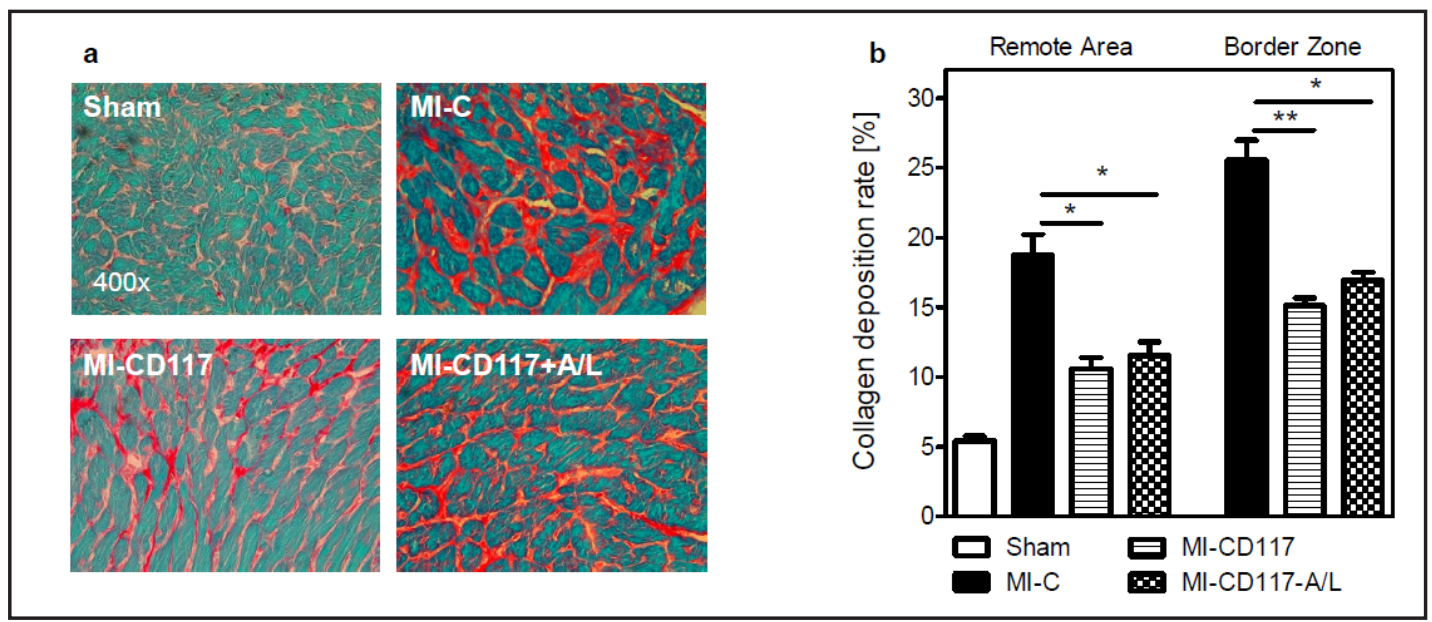

Fig. 8. Collagen deposition in remote area and border zone of infarct. Representative Fast Green FCF (myocytes)/Sirius Red (fibrosis) stainings at the border zone of the infarcted area of (a) Sham, (b) MI-C, (c) MI-CD117 and (d) MI-CD117+A/L. (e) Collagen deposition is significantly decreased in the remote area and border zone of infarct in both SC treated groups three weeks after MI. Data given as mean \pm SEM. ${ }^{*} p<0.05$, ** $\mathrm{p}<0.01$ vs. MI-C; $\mathrm{n}=6$.

Cell retention analysis is hampered by inconsistent eGFP expression

Despite the proposed ubiquitous expression of eGFP in the C57BL/6-Tg(CAGEGFP)10sb/J donor mice, only 35.3 $\pm 2.4 \%$ MACS-isolated viable CD117 ${ }^{+}$BMSC expressed eGFP in contrast to $87.5 \pm 6.8 \%$ of lung $\mathrm{CD} 117^{+} \mathrm{SC}(\mathrm{n}=5)$. To further assess a possible loss of eGFP expression during culture or differentiation, CD117 ${ }^{+}$SC were purified for eGFP expression with fluorescence activated cell sorting analysis (FACS re-analysis: $85.7 \%$, data not shown). This purified population was subjected to CFU assay and eGFP expression was determined after $12 \mathrm{~d}$ using flow cytometry and fluorescence microscopy. This analysis revealed that eGFP expression was diminished to $49.5 \pm 8.1 \%(n=2)$ in viable CD $117^{+}$cells. We concluded that using EGFP protein expression analysis would result in false negative results and largely underestimate the number of surviving cells. Hence, we did not equal protein expression with cell retention. In contrast, qRT-PCR analysis of eGFP mRNA expression gave more consistent results. CD $117^{+}$SC freshly isolated from eGFP+ transgenic mice or after

\section{KARGER}


Fig. 9. Quantitative real-time PCR analysis of heart and lung tissue 3 weeks after MI. qRT-PCR analysis for eGFP gene in heart and lung tissue. The eGFP expression in heart correlates with the expression found in lung. In MI-CD117+A/L group significantly more eGFP was detected in lung tissue as compared to MI-CD117. EGFP gene levels are given as $\Delta \mathrm{C}_{\mathrm{t}}=\mathrm{C}_{\text {teGFP }}-\mathrm{C}_{\mathrm{tGAPDH}}$ as eGFP is not expressed in Sham and MI-C. Expression levels were normalized to the expression of GAPDH. Data given as mean \pm SEM; $n=6$, *p $<0.05$ vs. MI-CD117.

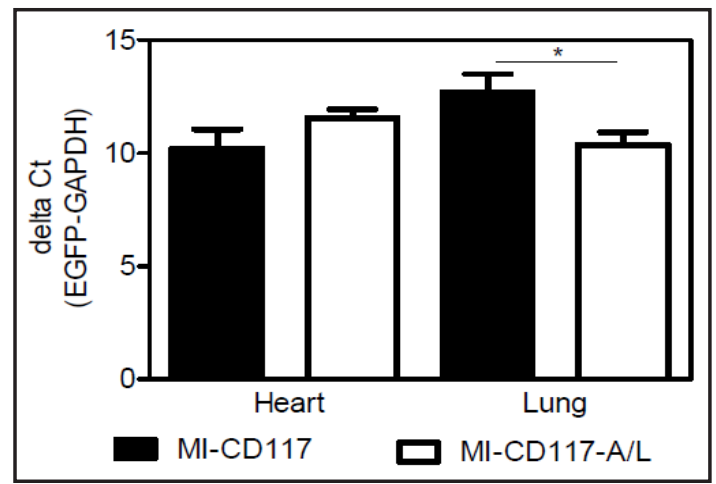

Fig. 10. Immunofluorescence analysis of eGFP+ implanted cells $24 \mathrm{~h}$ after intramyocardial injection. Representative cutout image of eGFP+ cells in the heart $24 \mathrm{~h}$ after implantation. Few cells were found to express EGFP+, which was not gradable using anti-GFP antibody and not found in later time points. $\mathrm{EGFP}+$ cells were captured to express VEGF (anti-VEGF; Alexa Fluor 568). Nuclei were counterstained with DAPI (blue). Scale bar: $5 \mu \mathrm{m}$. Images were acquired with 630x magnification using LSM 780 confocal microscope (Carl Zeiss).

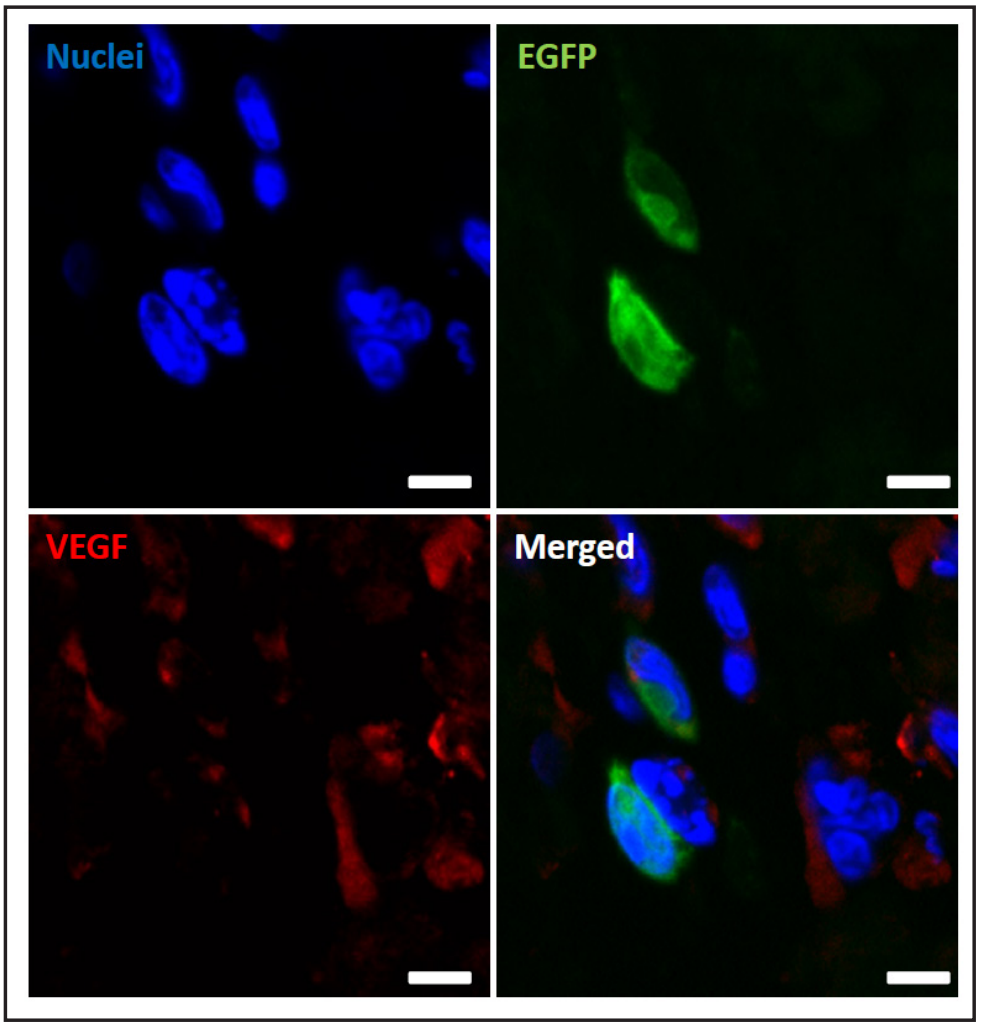

$12 \mathrm{~d}$ in CFU displayed a relative eGFP expression as high as in the positive control (eGFP+ heart tissue). Therefore, investigation of mRNA expression levels more closely resembled the magnitude of recovered cells and was further used in this study.

Three weeks after MI and cell implantation, explanted hearts were co-used for qRTPCR and immunohistochemistry analysis. Lungs were further analyzed for eGFP expression, since wash-out of intramyocardially implanted cells into the filter organs is an acknowledged process $[31,32]$. EGFP mRNA expression was found in the heart sections and correlates with the expression found in lungs (Fig. 9). The eGFP mRNA expression in the organs is plotted as $\triangle \mathrm{Ct}$ (relative to GAPDH mRNA expression), since it is not possible to compare the groups to Sham or MI-C. MI-CD117 group showed the tendency of a higher eGFP+ cell recovery in the heart, correlating to fewer cells migrating towards the lung in contrast to MI-CD117+A/L group (Fig. 9). A significantly higher cell number (1.2-fold) migrated towards the lung following AT2R stimulation, compared to MI-CD117, offering an explanation for diminished beneficial effects in the heart.

To assess the recovery and localization of (eGFP+) $\mathrm{CD} 117^{+} \mathrm{SC}$ in the tissue, selected heart slices were observed $24 \mathrm{~h}, 48 \mathrm{~h}$ and $7 \mathrm{~d}$ after cell implantation for eGFP expression. Independent 


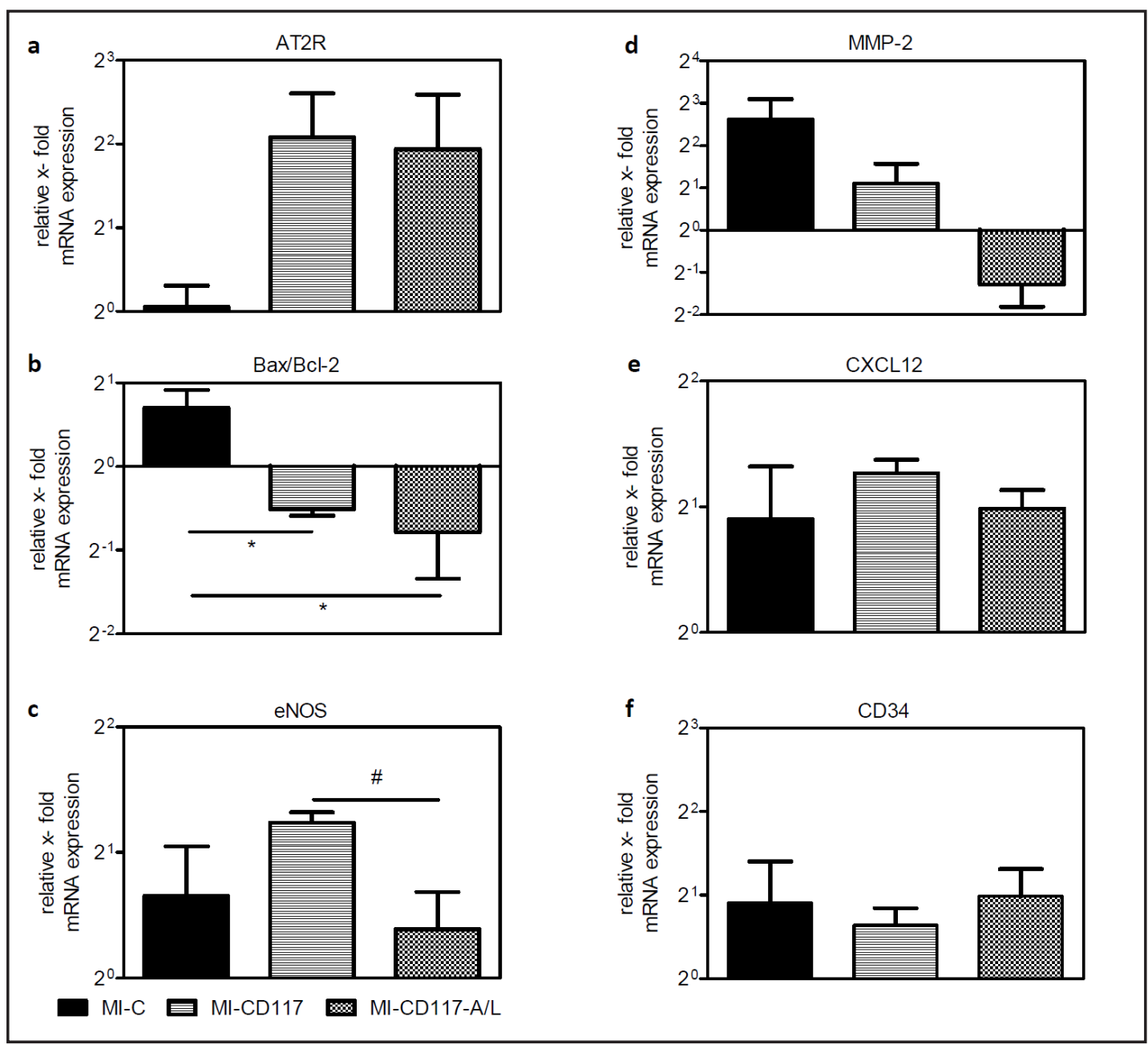

Fig. 11. Quantitative real-time PCR analysis of heart sections 3 weeks after MI. (a) qRT-PCR analysis for AT2R, (b) Bax/Bcl-2, (c) eNOS, (d) MMP-2, (e) CXCL12 and (f) CD34 genes, respectively in heart sections. SC implantation upregulates AT2R as well as eNOS and downregulates Bax/Bcl-2 ratio and MMP-2 expression. The average mRNA expression level in the Sham hearts was arbitrarily given a value of $1\left(2^{0}\right)$. Expression levels were normalized to the expression of GAPDH. Data given as mean \pm SEM; $n=6,{ }^{*} \mathrm{p}<0.05$ vs. MI-C; \#p $<0.05$ vs. MI-CD117.

of MI, few eGFP+ cells were found in hearts explanted 24h after cell implantation, but no later. The lack of EGFP positive cells later than $24 \mathrm{~h}$ is explainable regardingthe diminished EGFP protein expression in vitro as described above. However, immunohistochemistry analysis of the detected cells showed co-localization of eGFP and VEGFR-2 (Fig. 10) 24h after implantation.

\section{Stem cell implantation induces cardioprotective effects}

To clarify cardioprotective and anti-apoptotic effects of the implanted cells, mRNA levels of eNOS and Bax/Bcl-2 ratio were evaluated. An increased eNOS expression in the tissue is associated with an enhanced migratory capacity of HSC and improved neovascularization [33]. As shown in Fig. 11c, eNOS mRNA expression was 2.7-fold elevated in the MI-CD117 group compared to the MI-CD117+A/L group ( $\mathrm{p}<0.05$; Fig. 11c). The enhanced eNOS expression following AT2R stimulation, as proposed by other research groups [34], might be an immediate process and thus, not detectable three weeks after MI. Moreover, a reduced $\mathrm{Bax} / \mathrm{Bcl}-2$ ratio was reported to alleviate cardiomyocyte apoptosis [35] and is a key factor in cell survival. Our findings revealed Bax/Bcl-2 ratio was significantly reduced by 2.3 and

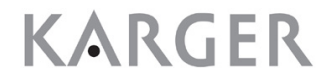




\section{Cellular Physiology Cell Physiol Biochem 2015;37:77-93 and Biochemistry

2.8-fold in MI-CD117 and MI-CD117+A/L, respectively when compared to MI-C (Fig. 11b), pointing to long-term anti-apoptotic effects after SC administration. The cardioprotective effects of stem cell injection were not additionally enhanced using AT2R stimulation.

Stem cell implantation regulates expression of MMP-2 and AT2R, but not Cxcl12

Previous studies revealed that inhibition of matrix metalloproteinase-2 (MMP-2) activity improves the survival rate after MI and increased MMP-2 ratios can be reversed with AT1R blockers [36, 37]. MMP-2 mRNA was considerably down-regulated in MI-CD117+A/L hearts compared to MI-CD117 (Fig. 11d). Different studies showed down-regulation of MMP-2 expression in the context of anti-fibrotic activity following AT2R stimulation [36, 37]. We contribute to this topic, showing a long-term inhibition of MMP-2 as an effect of AT2R stimulation. However, the MMP-2 expression does not accompany remarkably reduced fibrosis if compared with MI-CD117 group. No significant differences in Cxcl12 (Fig. 11e) and CD34 (Fig. 11f) mRNA regulation were detectable upon $\mathrm{CD}_{117^{+}} \mathrm{SC}$ injection, independent of stimulation. Thus, we speculate that the process of bone marrow stem cell migration is immediate and not perceptible after the remodeling process is completed. The expression of AT2R mRNA in both stem cell treated groups was visibly increased compared to MI-C (Fig. 11a).

\section{Discussion}

The current study aimed to assess the potential of bone marrow derived CD117 ${ }^{+} \mathrm{SC}$ to contribute to cardiac regeneration after MI. We further addressed the existing controversies on the beneficial effects of AT2R stimulation and their underlying mechanisms. A regenerative potential of the $\mathrm{CD} 117^{+} \mathrm{SC}$ population might be attributed to their differentiation into an endothelial-like phenotype, as shown in a 2D-Matrigel assay and with patch-clamp measurements in recent studies published by our group [17]. Using a co-culture setting involving the well characterized HL-1 cell line, we could show proof-of-principle that cellto-cell contact is a pre-requisite for $\mathrm{CD}_{117^{+}} \mathrm{SC}$ to improve cardiomyocyte vitality [38, 39]. Therefore, our findings are in line with a recent study demonstrating that cell-to-cell contact induces anti-apoptotic pathways in hematopoietic stem cells (HSC) indicating cardioprotective effects of HSC on cardiomyocytes in a co-culture of HSC with neonatal rat ventricular myocytes [40]. Moreover, enhanced paracrine effects, such as the secretion of VEGF and the expression of VEGFR-2, may be responsible for the quantitative increase in capillary density. In conjunction with our previous study, we demonstrate here that the improved cardiac function is likely a result of cardioprotective actions of CD117 $7^{+}$SC and not their electromechanically coupling to native cells. Contrary to previous studies [34], AT2R could not enhance the significant effect of stem cell implantation on cardiac function. Here, we approached AT2R stimulation by simultaneous treatment of CD $117^{+}$SC with Ang II and the AT1R inhibitor Losartan. Therefore, we could exclude a possible influence of AT1R signaling on the actions of stimulated $\mathrm{CD} 117^{+} \mathrm{SC}$. Most studies describe significant effects of AT2R signaling either in short-term in vitro experiments [41], by using undefined cell populations [34] or in a chronic, systemic AT2R stimulation approach [21]. We were able to reproduce short-term influences of AT2R stimulation in a 2-D Matrigel assay and in a co-culture of HL-1 cardiac muscle and $\mathrm{CD}_{117^{+}} \mathrm{SC}$. However, the transient stimulation of the defined $\mathrm{CD} 117^{+} \mathrm{SC}$ population is insufficient to add to proposed long-term beneficial effects for cardiac regeneration.

The detection and analysis of eGFP mRNA levels indicated that the implanted CD $117^{+}$SC physically contribute to the maintenance of cardiac function and to improved neovascularization. However, the retrieved eGFP+ cell number was very low and no injected cells were found $48 \mathrm{~h}$ after implantation using immunohistochemistry. Cell retention is limited by 1) the immediate washout following injection and thereafter because of 2) the hostile environment offered in the infarcted area, which lacks supporting cells or tissues, 


\section{Cellular Physiology Cell Physiol Biochem 2015;37:77-93 and Biochemistry

oxygen or nutritive substrates, but contains an excess of neutrophils and scavenger cells $[31,42,43]$. However, it has to be pointed out that CD117 ${ }^{+}$BMSC display inconsistent eGFP expression in the investigated transgenic mice strain, which further hampers cell retention analysis. Limitations of the use of GFP transgenic mice in bone marrow stem cells were described before [44] and should be taken into account for future studies.

Important unresolved mechanisms of AT2R signaling are its association with fibrosis, apoptosis and its action in angiogenesis $[45,46]$. We therefore chose to assess the influence of onetime AT2R stimulation of $\mathrm{CD} 117^{+} \mathrm{SC}$ on certain key factors involved in these mechanisms three weeks after MI.

A reduced Bax/Bcl-2 ratio has been reported to alleviate cardiomyocyte apoptosis. Increased Bcl-2 levels in the acute stage of MI and upregulation of Bax expression by chronic cellular responses of the affected myocytes against (mechanical) stress was described previously [35]. We demonstrated that the Bax/Bcl-2 ratio significantly decreased in both $\mathrm{SC}$ implanted groups, when compared to MI-C, pointing to long-term anti-apoptotic effects after SC administration. Despite the negative effect of AT2R stimulation on HL-1 vitality, Bax/ $\mathrm{Bcl}-2$ ratio was not significantly regulated by the transient AT2R stimulation of implanted CD $117^{+}$SC.

Moreover, an upregulation of eNOS expression has improved the migratory capacity of bone marrow-derived stem cells [33]. ENOS was further shown to play a role in ischemic neovascularization [47-49]. In our mouse model of myocardial infarction, eNOS mRNA expression in hearts injected with MI-CD117+A/L was significantly lower than in the MICD117 group. With respect to BMSC recruitment from the bone marrow, we could not find significant differences in mRNA levels of CD34 stem cell marker or stem cell homing factor CXCL12 (SDF-1). We speculate that SC recruitment is immediately induced, and not subject to changes in chronic ischemia. Likewise, it is unlikely associated with eNOS regulation at later time points.

MMP-2 is a key factor for micro-environmental adhesion, maturation and differentiation of stem cells [50,51], butalso for the breakdown of extracellular matrix in normal physiological processes and tissue remodeling. Controversies exist with respect to the regulation of MMP2 after MI. Studies suggest that inhibition of MMP-2 activity improves the survival rate after acute MI by preventing cardiac rupture and delays post-MI remodeling through a reduction in macrophage infiltration [52]. Interestingly, blockade of both Ang II receptors resulted in increased stiffness, fibrosis and increased MMP-2 activity, which was reversed with AT1R blockers [36, 37]. This is in line with our observations, as remarkably decreased MMP-2 mRNA levels were detected in the MI-CD117+A/L group.

However, the stimulation of AT2R on $\mathrm{CD} 117^{+} \mathrm{SC}$ provoked no additional improvement of cardiac functions, fibrosis or capillary density. Species differences, heterogenous SC subpopulations and variation in experimental setups in terms of stimulation might contribute to the different outcomes of previous studies and hamper a reliable comparison. Moreover, it has to be considered that the RAS is activated following MI and that this endogenous activation of AT1R/AT2R might mask specific effects of MI-CD117+A/L stimulated SC after transplantation. Yet, we observed a significant increase of cell alignment and cell elongation after AT2R stimulation in vitro, again pointing to a mechanism that might be masked by AT1R related-effects in vivo.

Therefore, our work contributes to the clarification of controversies about positive vs. negative AT2R effects after MI. We suggest that the positive effects seen after transient AT2R stimulation are short-term only and cannot significantly add to the beneficial effects of $\mathrm{CD} 117^{+} \mathrm{SC}$ implantation. Yet, an optimized stimulation approach of these cells (i.e. chronic and/or locally restricted to the site of transplantation) may provide a suitable means to exploit AT2R signaling for cardiac stem cell therapy. 


\section{Cellular Physiology Cell Physiol Biochem 2015;37:77-93 \begin{tabular}{l|l|l}
\hline DOI: 10.1159/000430335 & (C) 2015 S. Karger AG, Basel
\end{tabular} www.karger.com/cpb \\ Ludwig et al.: Potential of AT2R for Cardiac Stem Cell Therapy}

\section{Acknowledgements}

This work has been funded by the Federal Ministry of Education and Research Germany (FKZ 0312138A and FKZ 316159) and the State Mecklenburg-Western Pomerania with EU Structural Funds (ESF/IV-WM-B34-0030/10 and ESF/IV-BM-B35-0010/12), by the DFG (DA 1296-1), the German Heart Foundation (F/01/12) and by the FORUN Program of Rostock University Medical Centre (889001).

\section{Disclosure Statement}

The authors declare that they have no conflict of interest.

\section{References}

1 Orlic D, Kajstura J, Chimenti S, Jakoniuk I, Anderson SM, Li B, Pickel J, McKay R, Nadal-Ginard B, Bodine DM, Leri A, Anversa P: Bone marrow cells regenerate infarcted myocardium. Nature 2001;410:701-705.

2 Assmus B, Rolf A, Erbs S, Elsässer A, Haberbosch W, Hambrecht R, Tillmanns H, Yu J, Corti R, Mathey DG, Hamm CW, Säselbeck T, Tonn T, Dimmeler S, Dill T, Zeiher AM, Schächinger V, for the R-AMII Investigators: Clinical Outcome 2 Years After Intracoronary Administration of Bone Marrow-Derived Progenitor Cells in Acute Myocardial Infarction. Circ Heart Fail 2010;3:89-96.

3 Stamm C, Kleine H-D, Choi Y-H, Dunkelmann S, Lauffs J-A, Lorenzen Br, David A, Liebold A, Nienaber C, Zurakowski D, Freund M, Steinhoff G: Intramyocardial delivery of CD133+ bone marrow cells and coronary artery bypass grafting for chronic ischemic heart disease: Safety and efficacy studies. J Thorac Cardiovasc Surg 2007;133:717-725.

4 Hare JM, Fishman JE, Gerstenblith G, DiFede Velazquez DL, Zambrano JP, Suncion VY, Tracy M, Ghersin E, Johnston PV, Brinker JA, Breton E, Davis-Sproul J, Schulman IH, Byrnes J, Mendizabal AM, Lowery MH, Rouy D, Altman P, Wong Po Foo C, Ruiz P, Amador A, Da Silva J, McNiece IK, Heldman AW, George R, Lardo A: Comparison of allogeneic vs autologous bone marrow-derived mesenchymal stem cells delivered by transendocardial injection in patients with ischemic cardiomyopathy: The poseidon randomized trial. JAMA 2012;308:2369-2379.

5 Murry CE, Reinecke H, Pabon LM: Regeneration Gaps: Observations on Stem Cells and Cardiac Repair. JACC 2006;47:1777-1785.

6 Mirotsou M, Jayawardena TM, Schmeckpeper J, Gnecchi M, Dzau VJ: Paracrine mechanisms of stem cell reparative and regenerative actions in the heart. J Mol Cell Cardiol 2011;50:280-289.

7 Huang C, Gu H, Yu Q, Manukyan MC, Poynter JA, Wang M: Sca-1+ Cardiac Stem Cells Mediate Acute Cardioprotection via Paracrine Factor SDF-1 following Myocardial Ischemia/Reperfusion. PLoS ONE 2011;6:e29246.

8 Takahashi M, Li T-S, Suzuki R, Kobayashi T, Ito H, Ikeda Y, Matsuzaki M, Hamano K: Cytokines produced by bone marrow cells can contribute to functional improvement of the infarcted heart by protecting cardiomyocytes from ischemic injury. Am J Physiol - Heart Circ Physiol 2006;291:H886-H893.

9 Murry CE, Soonpaa MH, Reinecke H, Nakajima H, Nakajima HO, Rubart M, Pasumarthi KBS, Ismail Virag J, Bartelmez SH, Poppa V, Bradford G, Dowell JD, Williams DA, Field LJ: Haematopoietic stem cells do not transdifferentiate into cardiac myocytes in myocardial infarcts. Nature 2004;428:664-668.

10 Scherschel JA, Soonpaa MH, Srour EF, Field LJ, Rubart M: Adult Bone Marrow-derived Cells Do Not Acquire Functional Attributes of Cardiomyocytes When Transplanted into Peri-infarct Myocardium. Mol Ther 2008;16:1129-1137.

11 Kubo H, Berretta RM, Jaleel N, Angert D, Houser SR: c-Kit+ Bone Marrow Stem Cells Differentiate into Functional Cardiac Myocytes. Clin Transl Sci 2009;2:26-32.

12 Fazel S, Cimini, Massimo, Chen, Liwen, Li, Shuhong, Li, Ren-Ke: Cardioprotective c-kit+ cells are from the bone marrow and regulate the myocardial balance of angiogenic cytokines. J Clin Invest 2006;116:18651877.

13 Li T-S, Hamano K, Nishida M, Hayashi M, Ito H, Mikamo A, Matsuzaki M: CD117+ stem cells play a key role in therapeutic angiogenesis induced by bone marrow cell implantation. Am J Physiol - Heart Circ Physiol 2003;285:H931-H937. 


\section{Cellular Physiology Cell Physiol Biochem 2015;37:77-93 \begin{tabular}{l|l|l} 
DOI: 10.1159/000430335 & (C) 2015 S. Karger AG, Base
\end{tabular} \\ Ludwig et al.: Potential of AT2R for Cardiac Stem Cell Therapy}

14 Gnecchi M, Zhang Z, Ni A, Dzau VJ: Paracrine Mechanisms in Adult Stem Cell Signaling and Therapy. Circ Res 2008;103:1204-1219.

15 Loffredo Francesco S, Steinhauser Matthew L, Gannon J, Lee Richard T: Bone Marrow-Derived Cell Therapy Stimulates Endogenous Cardiomyocyte Progenitors and Promotes Cardiac Repair. Cell Stem Cell 2011;8:389-398.

16 Uemura R, Xu M, Ahmad N, Ashraf M: Bone Marrow Stem Cells Prevent Left Ventricular Remodeling of Ischemic Heart Through Paracrine Signaling. Circ Res 2006;98:1414-1421.

17 Ludwig M, Skorska A, Tölk A, Hopp HH, Patejdl R, Li J, Steinhoff G, Noack T: Characterization of ion currents of murine CD117pos stem cells in vitro and their modulation under AT2R stimulation. Acta Physiol 2013;208:274-287.

18 Ludwig M, Patejdl R, Steinhoff G, Noack T: Comparison of the electrophysiological properties of murine CD117pos stem cells with vascular smooth muscle cells (guinea-pig portal vein). Trace Elem Electrolytes DOI:10.5414/TEX01359

19 Breitbach M, Bostani T, Roell W, Xia Y, Dewald O, Nygren JM, Fries JWU, Tiemann K, Bohlen H, Hescheler J, Welz A, Bloch W, Jacobsen SEW, Fleischmann BK: Potential risks of bone marrow cell transplantation into infarcted hearts. Blood 2007;110:1362-1369.

20 Fernandes S, Amirault J-C, Lande G, Nguyen J-M, Forest V, Bignolais O, Lamirault G, Heudes D, Orsonneau J-L, Heymann M-Fo, Charpentier F, Lemarchand P: Autologous myoblast transplantation after myocardial infarction increases the inducibility of ventricular arrhythmias. Cardiovasc Res 2006;69:348-358.

21 Altarche-Xifró W, Curato C, Kaschina E, Grzesiak A, Slavic S, Dong J, Kappert K, Steckelings UM, Imboden H, Unger T, Li J: Cardiac c-kit+AT2+ Cell Population is Increased in Response to Ischemic Injury and Supports Cardiomyocyte Performance. Stem Cells 2009;27:2488-2497.

22 de Gasparo M, Catt KJ, Inagami T, Wright JW, Unger T: International Union of Pharmacology. XXIII. The Angiotensin II Receptors. Pharmacol Rev 2000;52:415-472.

23 Jones ES, Vinh A, McCarthy CA, Gaspari TA, Widdop RE: AT2 receptors: Functional relevance in cardiovascular disease. Pharmacol Ther 2008;120:292-316.

24 Meggs LG, Coupet J, Huang H, Cheng W, Li P, Capasso JM, Homcy CJ, Anversa P: Regulation of angiotensin II receptors on ventricular myocytes after myocardial infarction in rats. Circ Res 1993;72:1149-62.

25 Leri A, Liu Y, Li B, Fiordaliso F, Malhotra A, Latini R, Kajstura J, Anversa P: Up-Regulation of AT1 and AT2 Receptors in Postinfarcted Hypertrophied Myocytes and Stretch-Mediated Apoptotic Cell Death. Am J Pathol 2000;156:1663-1672.

26 Kaschina E, Grzesiak A, Li J, Foryst-Ludwig A, Timm M, Rompe F, Sommerfeld M, Kemnitz UR, Curato C, Namsolleck P, Tschope C, Hallberg A, Alterman M, Hucko T, Paetsch I, Dietrich T, Schnackenburg B, Graf K, Dahlof B, Kintscher U, Unger T, Steckelings UM: Angiotensin II Type 2 Receptor Stimulation: A Novel Option of Therapeutic Interference With the Renin-Angiotensin System in Myocardial Infarction? Circulation 2008;118:2523-2532.

27 Rompe F, Artuc M, Hallberg A, Alterman M, Stroder K, Thone-Reineke C, Reichenbach A, Schacherl J, Dahlof B, Bader M, Alenina N, Schwaninger M, Zuberbier T, Funke-Kaiser H, Schmidt C, Schunck W-H, Unger T, Steckelings UM: Direct Angiotensin II Type 2 Receptor Stimulation Acts Anti-Inflammatory Through Epoxyeicosatrienoic Acid and Inhibition of Nuclear Factor kappa B. J Hypertens 2010;55:924-931.

28 Ichihara S, Senbonmatsu T, Price E, Ichiki T, Gaffney FA, Inagami T: Angiotensin II Type 2 Receptor Is Essential for Left Ventricular Hypertrophy and Cardiac Fibrosis in Chronic Angiotensin II - Induced Hypertension. Circulation 2001;104:346-351.

29 Fang S, Wei J, Pentinmikko N, Leinonen H, Salven P: Generation of Functional Blood Vessels from a Single c-kit+ Adult Vascular Endothelial Stem Cell. PLoS Biol 2012;10:e1001407.

30 Gaebel R, Furlani D, Sorg H, Polchow B, Frank J, Bieback K, Wang W, Klopsch C, Ong L-L, Li W, Ma N, Steinhoff G: Cell Origin of Human Mesenchymal Stem Cells Determines a Different Healing Performance in Cardiac Regeneration. PLoS ONE 2011;6:e15652.

31 Lang C, Lehner S, Todica A, Boening G, Zacherl M, Franz W-M, Krause B, Bartenstein P, Hacker M, David R: In-vivo comparison of the acute retention of stem cell derivatives and fibroblasts after intramyocardial transplantation in the mouse model. Eur J Nucl Med Mol Imaging 2014;41:2325-2336.

32 Wang W, Jin P, Wang L, Yang Z, Hu S, Gao B, Zhang H: Impact of Escaped Bone Marrow Mesenchymal Stromal Cells on Extracardiac Organs After Intramyocardial Implantation in a Rat Myocardial Infarction Model. Cell Transpl 2010;19:1599-1607. 


\section{Cellular Physiology Cell Physiol Biochem 2015;37:77-93 \begin{tabular}{l|l|l}
\hline DOI: 10.1159/000430335 & (C) 2015 S. Karger AG, Basel
\end{tabular} www.karger.com/cpb \\ Ludwig et al.: Potential of AT2R for Cardiac Stem Cell Therapy}

33 Sasaki K-i, Heeschen C, Aicher A, Ziebart T, Honold J, Urbich C, Rossig L, Koehl U, Koyanagi M, Mohamed A, Brandes RP, Martin H, Zeiher AM, Dimmeler S: Ex vivo pretreatment of bone marrow mononuclear cells with endothelial NO synthase enhancer AVE9488 enhances their functional activity for cell therapy. Proc Natl Acad Sci U S A 2006;103:14537-14541.

34 Xu Y, Hu X, Wang L, Jiang Z, Liu X, Yu H, Zhang Z, Chen H, Chen H, Steinhoff G, Li J, Jianan W: Preconditioning via Angiotensin Type 2 Receptor Activation Improves Therapeutic Efficacy of Bone Marrow Mononuclear Cells for Cardiac Repair. PLoS ONE 2013;8:e82997.

35 Misao J, Hayakawa Y, Ohno M, Kato S, Fujiwara T, Fujiwara H: Expression of bcl-2 Protein, an Inhibitor of Apoptosis, and Bax, an Accelerator of Apoptosis, in Ventricular Myocytes of Human Hearts With Myocardial Infarction. Circulation 1996;94:1506-1512.

36 Yang D, Ma S, Li D, Tang B, Yang Y: Angiotensin II receptor blockade improves matrix metalloproteinases/ tissue inhibitor of matrix metalloproteinase-1 balance and restores fibronectin expression in rat infarcted myocardium. Biochem Biophys Res Commun 2009;388:606-611.

37 Brassard P, Amiri F, Schiffrin EL: Combined Angiotensin II Type 1 and Type 2 Receptor Blockade on Vascular Remodeling and Matrix Metalloproteinases in Resistance Arteries. J Hypertens 2005;46:598-606.

38 Li H, Tang M, Liang H, Li Y, Wang J, Song Y, Zheng Y, Xi J, Zhang J, Hescheler J, Zhu M: Coculture of Embryonic Ventricular Myocytes and Mouse Embryonic Stem Cell Enhance Intercellular Signaling by Upregulation of Connexin43. Cell Physiol Biochem 2013;32:53-63.

39 Gong X, Fan G, Wang W, Wang G: Trimetazidine Protects Umbilical Cord Mesenchymal Stem Cells Against Hypoxia and Serum Deprivation Induced Apoptosis by Activation of Akt. Cell Physiol Biochem 2014;34:2245-2255.

40 Rosenberg M, Lutz M, Kuhl C, Will R, Eckstein V, Krebs J, Katus H, Frey N: Coculture with hematopoietic stem cells protects cardiomyocytes against apoptosis via paracrine activation of AKT. J Transl Med 2012;10:115.

41 Bosnyak S, Welungoda IK, Hallberg A, Alterman M, Widdop RE, Jones ES: Stimulation of angiotensin AT2 receptors by the non-peptide agonist, Compound 21, evokes vasodepressor effects in conscious spontaneously hypertensive rats. Br J Pharmacol 2010;159:709-716.

42 Bartunek J, Sherman W, Vanderheyden M, Fernandez-Aviles F, Wijns W, Terzic A: Delivery of Biologics in Cardiovascular Regenerative Medicine. Clin Pharmacol Ther 2009;85:548-552.

43 Lang C, Lehner S, Todica A, Boening G, Franz W-M, Bartenstein P, Hacker M, David R: Positron emission tomography based in-vivo imaging of early phase stem cell retention after intramyocardial delivery in the mouse model. Eur J Nucl Med Mol Imaging 2013;40:1730-1738.

44 Van Overstraeten-Schlaegel N, Delgaudine M, Beguin Y, Gothot A: Limitations of the use of GFP transgenic mice in bone marrow transplantation studies. Leuk Lymphoma 2006;47:1392-1393.

45 Savoia C, Volpe M: Angiotensin receptor modulation and cardiovascular remodeling. J Renin Angiotensin Aldosterone Syst 2011;12:381-384.

46 Volpe M, Musumeci B, De Paolis P, Savoia C, Morganti A: Angiotensin II AT2 receptor subtype: an uprising frontier in cardiovascular disease? J Hypertens 2003;21:1429-1443.

47 Bir S, Xiong Y, Kevil C, Luo J: Emerging role of PKA/eNOS pathway in therapeutic angiogenesis for ischaemic tissue diseases. Cardiovasc Res 2012;95:7-18.

48 MacLauchlan S, Yu J, Parrish M, Asoulin TA, Schleicher M, Krady MM, Zeng J, Huang PL, Sessa WC, Kyriakides TR: Endothelial nitric oxide synthase controls the expression of the angiogenesis inhibitor thrombospondin 2. Proc Natl Acad Sci U S A 2011;108:E1137-E1145.

49 Chen X, Gu M, Zhao X, Zheng X, Qin Y, You X: Deterioration of Cardiac Function After Acute Myocardial Infarction is Prevented by Transplantation of Modified Endothelial Progenitor Cells Overexpressing Endothelial NO Synthases. Cell Physiol Biochem 2013;31:355-365.

50 Lapidot T, Dar A, Kollet O: How do stem cells find their way home? Blood 2005;106: 1901-1910.

51 Qu Z, Xu H, Tian Y, Jiang X: Atorvastatin Improves Microenvironment to Enhance the Beneficial Effects of BMSCs Therapy in a Rabbit Model of Acute Myocardial Infarction. Cell Physiol Biochem 2013;32:380-389.

52 Matsumura S-i, Iwanaga S, Mochizuki S, Okamoto H, Ogawa S, Okada Y: Targeted deletion or pharmacological inhibition of MMP-2 prevents cardiac rupture after myocardial infarction in mice. Clin Invest 2005;115:599-609. 